\title{
Albian-Turonian stage boundaries and subdivisions in the western Portuguese Basin, with special emphasis on the Cenomanian-Turonian boundary in the ammonite facies and rudist facies
}

\author{
PIERRE-YVES BERTHOU
}

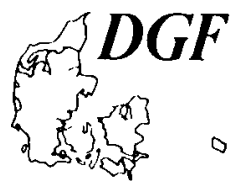

\begin{abstract}
Berthou, P.-Y.: Albian-Turonian stage boundaries and subdivisions in the western Portuguese Basin, with special emphasis on the Cenomanian-Turonian boundary in the ammonite facies and rudist facies. Bull. geol. Soc. Denmark, vol. 33, pp. 41-55, Copenhagen, September, 10th, 1984. https://doi.org/10.37570/bgsd-1984-33-04
\end{abstract}

\begin{abstract}
The precise chronostratigraphy from the Aptian-Albian boundary to the upper Cenomanian has been established mainly on the distribution of large benthic Foraminifera and dinocysts. Ammonites are rare, and nannofossils and planktonic Foraminifera are absent. In this study species with well-known stratigraphic ranges were used and, where possible, reference is made to sequences dated with ammonites. The upper Cenomanian, the Cenomanian-Turonian boundary and the lower Turonian were studied first in the ammonite facies, where Choffat at the turn of the century described different species of Vascoceras. The type sections contain Cenomanian ammonites (Euomphaloceras, Calycoceras and Pseudocalycoceras. Vascoceras ex gr. gamai appears in the Cenomanian Metoicoceras geslinianum Zone. Above this zone, Spathites (Jeanrogericeras) subconciliatus marks the Neocardioceras juddii Zone, here placed in the uppermost Cenomanian. Thus, the lower Turonian is marked by the appearance of Fagesia superstes and $F$. thevestensis. The different sections in the rudist facies and ammonite facies are correlated. Only Radiolites peroni seems to appear in the lower Turonian. The presence of Durania arnaudi in the Turonian depends on the assignment of the Neocardioceras juddii Zone to the uppermost Cenomanian. Only the lower part of the Turonian has been identified in Portugal. The stratigraphy of the coarse sandstones which separate the lower Turonian from the Coniacian horizon with Hemitissotia ceadourensis, is poorly known.
\end{abstract}

Pierre-Yves Berthou. Laboratoire de Géologie des Bassins sédimentaires et L.A. 319, Université P. \& M. Curie, tours 14-15, 4 étage, 4 place Jussieu, 75230 Paris cedex O5, France. February 27th, 1984.

\section{Introduction}

The presence of Aptian-Albian, Cenomanian and Turonian in the Western Portuguese Basin (Fig. 1) has been known since Choffat's work at the end of the last century $(1885,1886,1897 \mathrm{a}, 1897 \mathrm{~b}$, $1898,1900)$. Choffat based his datings on the few ammonite-bearing levels - in the Aptian-Albian and in the lower and Middle Cenomanian, in particular - whereas between these beds, Choffat's stratigraphy is speculative and often based more on lithology than on palaeontology. Choffat's stage and substage boundaries of the Cretaceous are always vaguely stated. His lithological formations were defined mainly for mapping purposes and not for chronostratigraphical interpretations, and therefore often transgress stages and substages. In Choffat's view, local subdivisions such as "Couches
d'Almargem" or "Bellasien", the definitions of which are based on lithology only, are more important than their chronostratigraphical positions (Fig. 9).

It has not been an easy task to establish the precise chronostratigraphy of the middle and upper Cretaceous because of the scarceness of ammonite-bearing levels (also, specimens are rare and diversity is low) and the lack of planktonic Foraminifera (except Favusella washitensis) and nannofossils (except at the level of Neolobites vibrayeanus). I have used species from different fossil groups, species with well-known stratigraphic ranges, often in conjunction with sequences dated with ammonites, In addition, correlations were made with DSDP site 398D (leg 47B) on the Vigo Seamount off Portugal (De Graciansky et al. 1982; Masure \& Hasenboehler 1981 , in press). In a few cases I have used dino- 


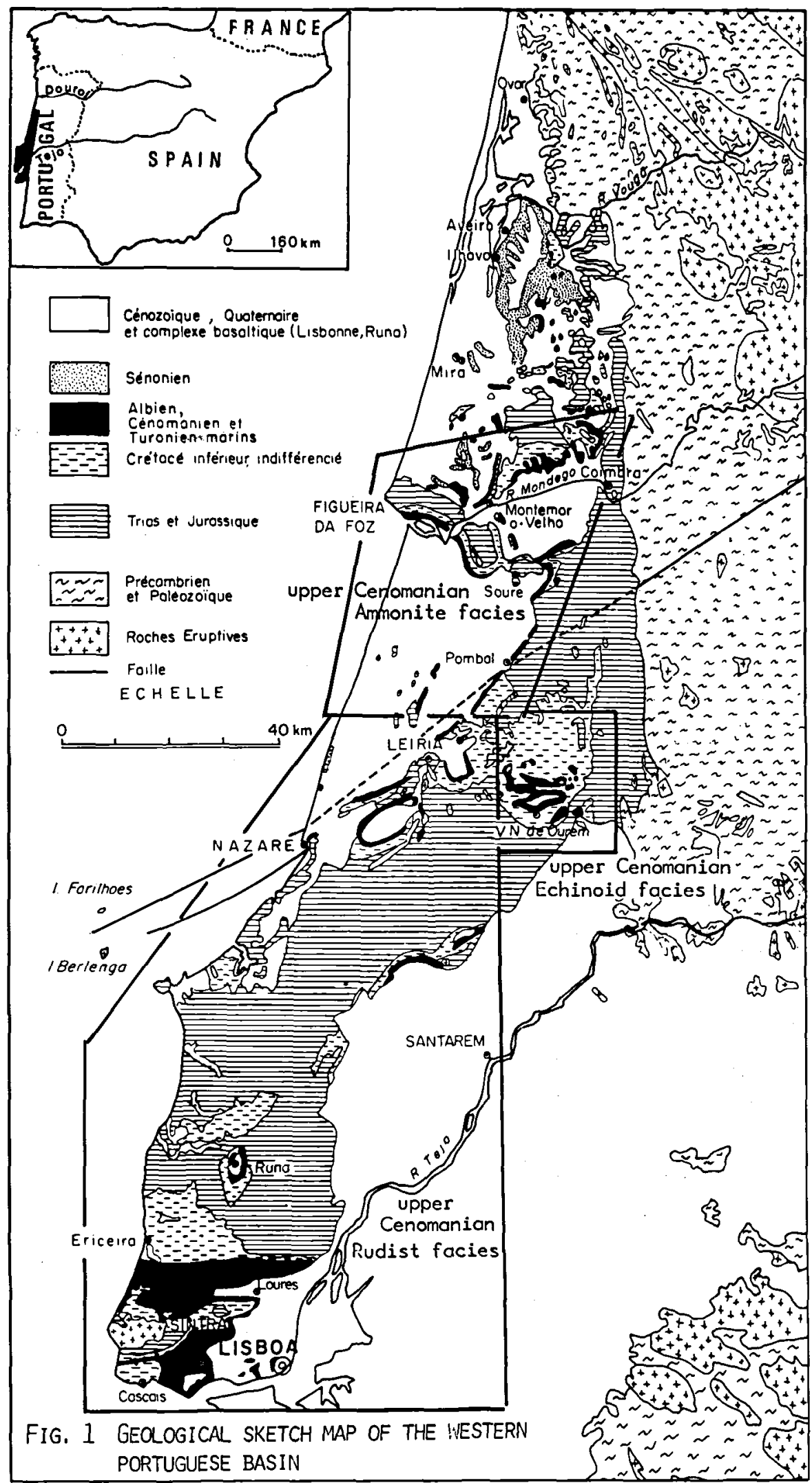


cysts (rarely pollen and spores), Ostracoda, large benthic Foraminifera, rudists, and echinoids. Ammonites were used only for the Cenomanian-
Turonian boundary in the type section with vascoceratids.

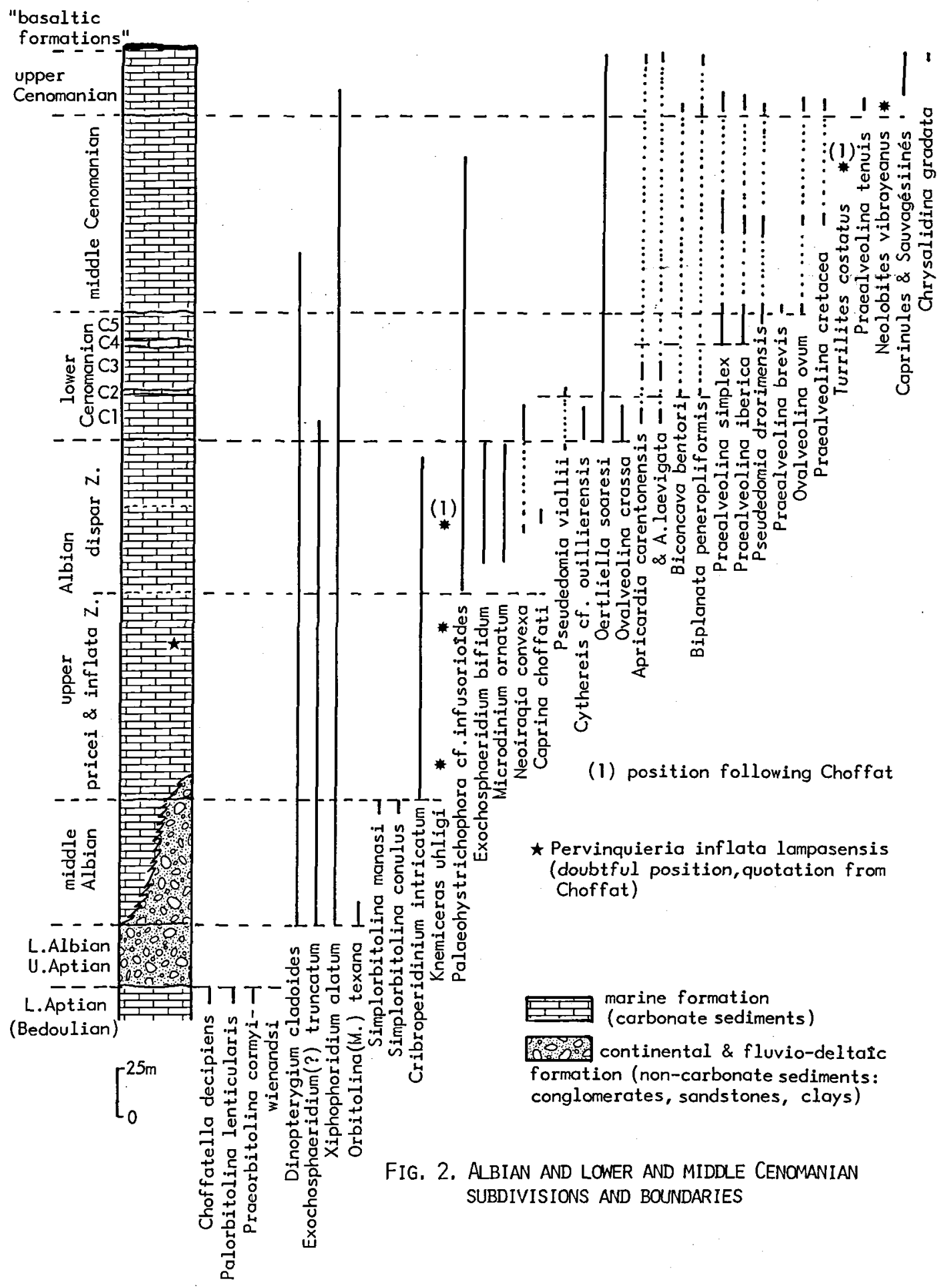

Fig. 2. Albian, Lower and Middle Cenomanian subdivisions and boundaries. 


\section{The Aptian-Albian boundary (Fig. 2)}

The lower Aptian marls and limestones are devoid of ammonites but contain a well-known Bedoulian assemblage of Foraminifera, with $\mathrm{Pa}$ lorbitolina lenticularis (Blumenbach), Praeorbitolina cormyi-wienandsi Schroeder and Choffatella decipiens Schlumberger. There is a discontinuity surface at the top of the lower Aptian and the uppermost layers are occasionally missing (Martins Carvalho et al. 1982).

Overlying the lower Aptian, there are continental and fluviatile deposits, previously assigned to the upper Aptian (Rey 1972, 1979). It now appears that these deposits correspond, in part, to the lower Albian, but it is still not possible to separate upper Aptian from lower Albian deposits (Berthou et al. 1981; Hasenboehler 1981; Berthou \& Hasenboehler in press).

\section{Middle and upper Albian (Fig. 2)}

The oldest dated deposits of the Albian-Cenomanian transgression are of middle Albian age, ac- cording to the stratigraphic range of the dinocysts Dinopterygium cladoides Deflandre 1935, Xiphophoridium alatum (Cookson \& Eisenack 1962), Exochosphaeridium(?) truncatum (Davey 1969) (Verdier 1975; Fauconnier 1977; Davey 1979; Foucher 1981). These dinocysts occur in both facies of the Middle Albian, viz. marine, shallow-water limestones and marls and deltaic sandstones, shales and silts, respectively (Hasenboehler 1981; Berthou \& Hasenboehler in press). The same assemblage (except Exochosphaeridium(?) truncatum) appears in the middle Albian of site 398D (leg 47B) (Masure \& Hasenboehler 1981, in press).

The lower part of the middle Albian contains Orbitolina (M.) texana (Roemer) and the upper part Simplorbitolina manasi Ciry \& Rat and $S$. conulus Schroeder. These species disappear before the appearance of Cribroperidinium intricatum Davey 1969, an upper Albian dinocyst, which exists also in the upper Albian of site 398 $D$. This species was found in many sections in the Lisbon area.

There is good agreement between the stratigraphical data based on Foraminifera and dino-

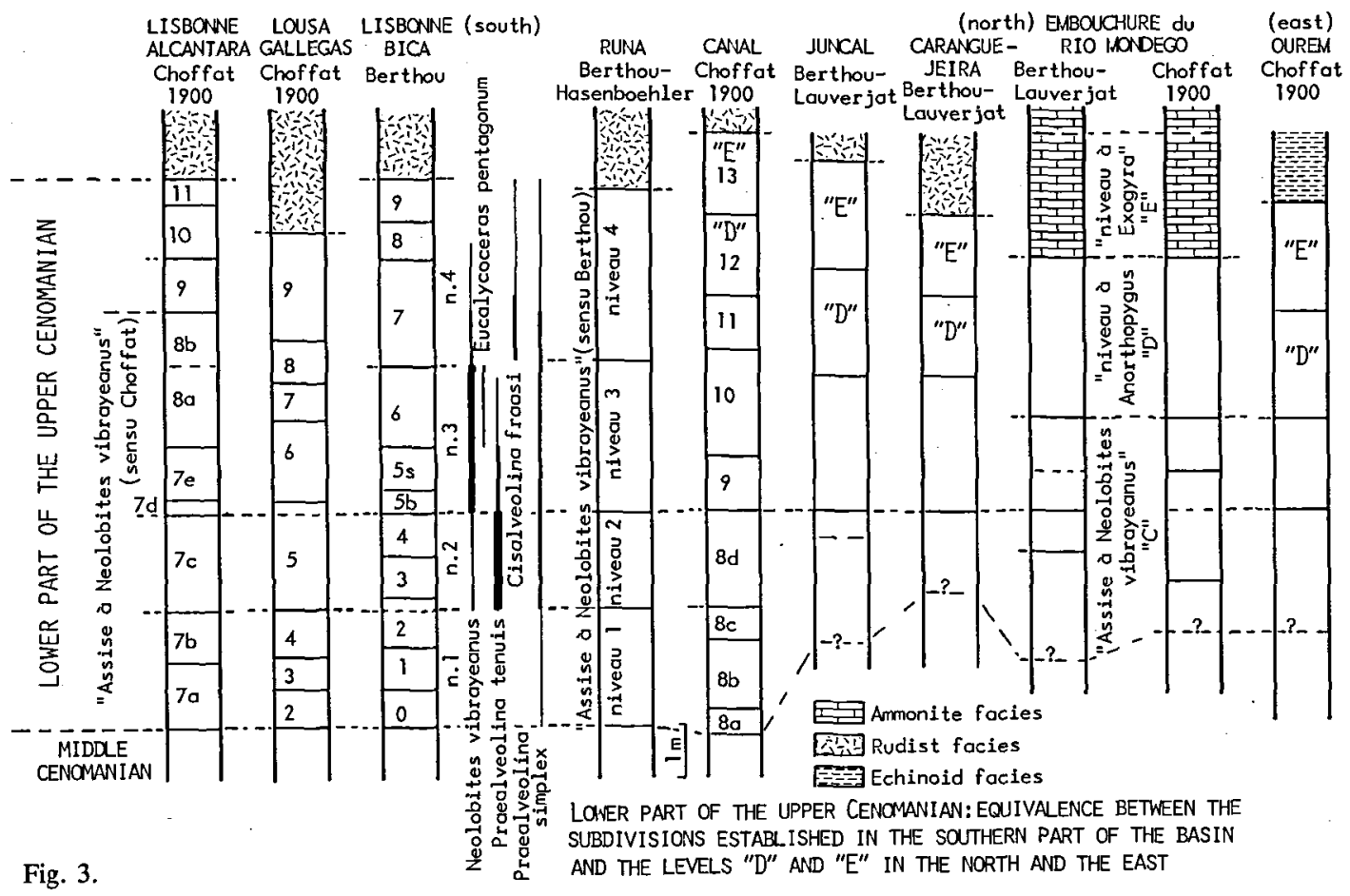


cysts (Simplorbitolina manasi and S. conulus, which do not reach the upper Albian, disappear slightly before Cribroperidinium intricatum) and those based on ammonites (Berthou \& Schroeder 1979).

The basal part of the upper Albian contains the first Knemiceras uhligi (Choffat), and Pervinquieria inflata lampasense (Choffat) appears a little higher. These beds probably correspond to the Pervinquieria pricei and $P$. inflata zones (Amedro 1981) and extend upwards until the first appearance of Palaeohystrichophora cf. infusorioides Davey \& Verdier 1973, Microdinium ornatum Cookson \& Eisenack 1960, and Exochosphaeridium bifidum (Clarke \& Verdier 1967), which mark the transition to the Stoliczkaia dispar Zone. Palaeohystrichophora cf. infusorioides exists at the same level at site 398D.

The lower part of the Stoliczkaia dispar Zone contains the essentially Albian rudist beds with Radiolites cantabricus Douvillé, Polyconites subverneuili Douvillé, Horiopleura lamberti(?) Munier-Chalmas, Pseudotoucasia santanderensis (Douvillé), and Caprina choffati (Douvillé). A clear discontinuity surface divides the dispar Zone in two parts. The upper part of the zone contains the earliest Pseudedomia viallii (Colalongo) and Favusella washitensis (Carsey).
Ammonites are absent from the upper part of the upper Albian and from the lower Cenomanian. There is an important discontinuity surface immediately below the appearance of a microfauna (Ostracoda and Foraminifera) of Cenomanian type, so, based on current knowledge, this discontinuity may correspond to the AlbianCenomanian boundary.

\section{Lower and middle Cenomanian (Fig.2)}

I have divided the lower Cenomanian in five levels: C1, C2, C3, C4 and C5. The lowermost Cenomanian (C1) marls or limestones are marked by the Ostracoda Cythereis cf. ouillierensis Babinot, Oertliella soaresi Colin \& Lauverjat, and Ovalveolina crassa De Castro (Berthou \& Schroeder 1978, Babinot 1980, Damotte et al. 1981, Neumann et al. 1981). Neoiraqia convexa Danilova which appears already in the upper Albian, is abundant in the beds with Ovalveolina crassa, and the marls between these beds contain Cenomanian rudists (Apricardia carentonensis (d'Orbigny) and $A$. laevigata ('Orbigny). Favusella washitensis (Carsey) is present in this level of the lower Cenomanian. It is possible that Ovalveolina crassa appears in the uppermost Al-
INTERPRETATION

P. CHOFFAT 1900

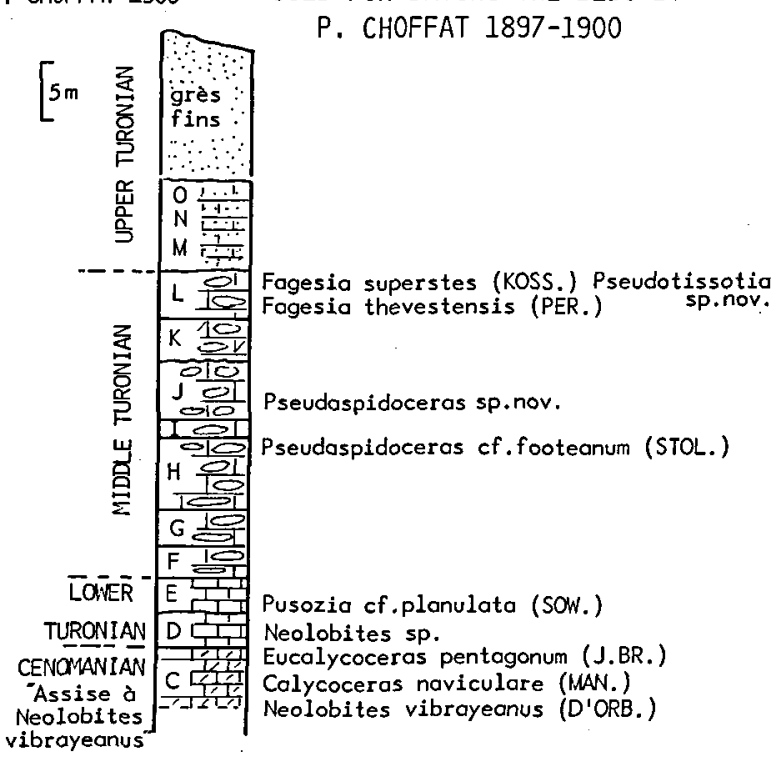

NEW AMMONITES WITHOUT STRATIGRAPHICAL VALUE FOR P. CHOFFAT 1897-1900 $\left\{\begin{array}{l}\text { Ammonites A (1897) } \\ =\text { Voscoceras ganai-mundae, V. barcoicensis } \\ \text { Ammonites A, renflées (1897) } \\ =\text { Vascoceras kossmati, V.harttiformis CHOFFAT } \\ \text { V. douvillei } \\ 1898\end{array}\right.$
Ammonites A, renflées (1897)
$=$ Vascoceras douvillei OHOFFAT 1898
Vascoceras subconciliatum OHOFFAT 1898
$\left(\begin{array}{l}\text { Ammonites A (1897) } \\ =\text { Vascoceras sp. }\end{array}\right.$
$\begin{aligned} & \text { Ammonites A (1897) } \\ & =\text { Vascoceras gamai-mundae aHOFFAT } 1898 \\ & \text { V. barcoicensis aHOFFAT 1898 }\end{aligned}$

Fig. 4. P.Choffat's interpretation of the CEnOMano-turonian aMMONITE facies 
bian - the question is still under discussion - so level $\mathrm{C} 1$ will in the future, perhaps, be placed at the top of the Albian. More palaeontological data are required for a decision and for the time being I prefer to place the species in the lowermost Cenomanian.

Above, in level C2 ( $2 \mathrm{~m}$ only) a Cenomanian association is found, containing Pseudedomia viallii (Colalongo), Biconcava bentori Hamaoui \& Saint Marc, Biplanata peneropliformis Hamaoui \& Saint Marc, and Heteroporella lepina Praturlon.

Level C3 yields numerous Orbitolina (Conicorbitolina) cuvillieri (Moullade)-conica (d'Archiac) (which appeared already in the upper Albian), and at level C4 (2 m) the first Praealveolina simplex Reichel and P. iberica Reichel are found.
The uppermost level, C5, contains Pseudedomia drorimensis Reiss, Hamaoui \& Ecker and Ichthyosarcolites triangularis Desmarest.

Level C5 ends with marls, above which there is a bed of hard limestones $(2-3 \mathrm{~m})$. This unit can be found in the entire Lisbon area and contains abundant Praealveolina iberica, $P$. pennensis Reichel, Ovalveolina ovum (d'Orbigny), and Praealveolina brevis Reichel, marking the base of the middle Cenomanian.

The higher part yields Turrilites costatus (Lamarck). The middle Cenomanian ends with regressive dolomitic limestones and locally gypsiferous shales.

The contact between the middle Cenomanian slopes and the cliffs of the massive upper Cenomanian limestones is easily visible at surface.

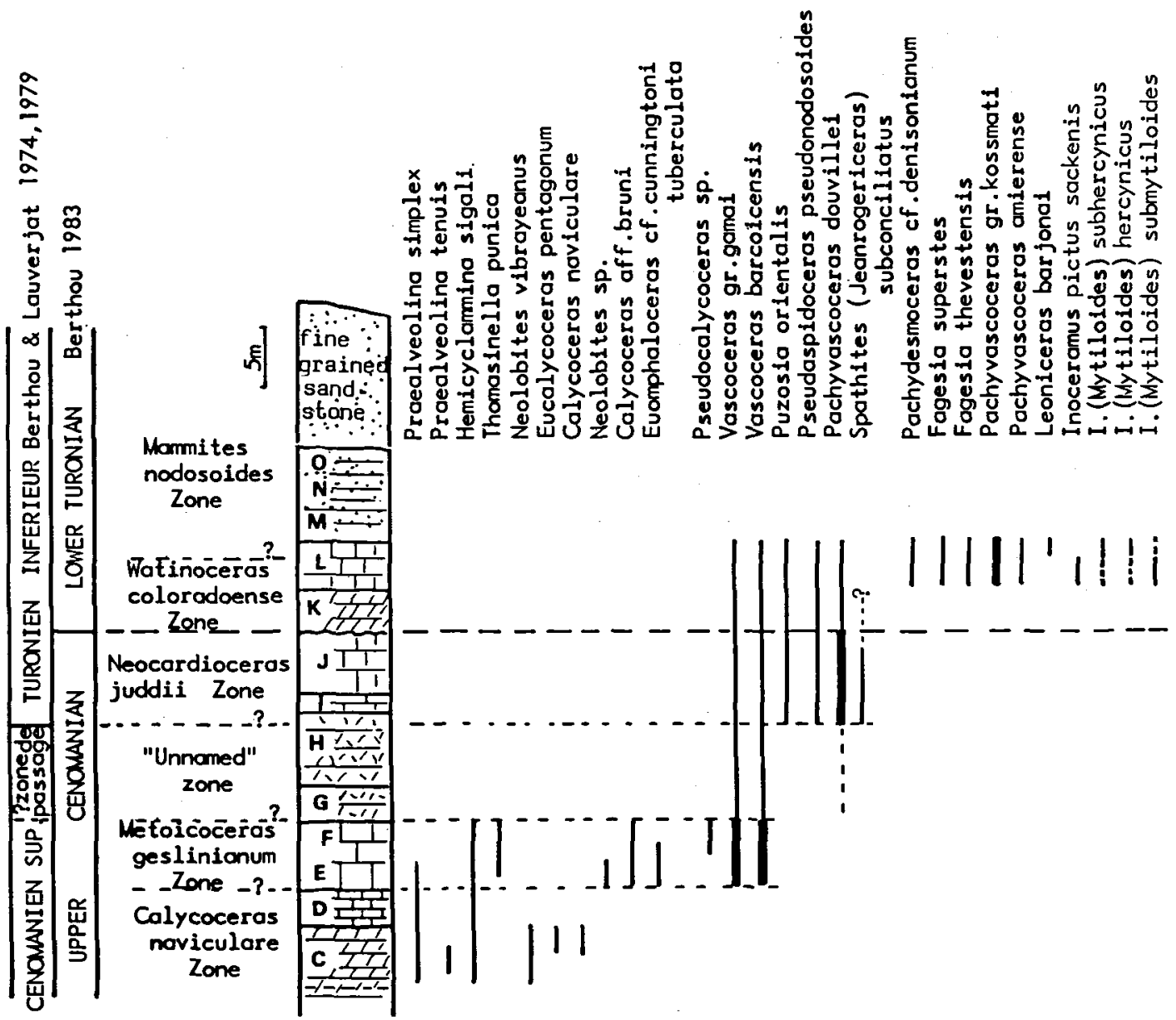

Fig.5. AMMONITE FACIES: REPARTITION OF THE MAIN MACRO- AND MICROFAUNA, POSITION OF THE CENOMANIAN - TURONIAN BONDARY 


\section{Upper Cenomanian}

The upper Cenomanian is divided into two parts. The lower part - here designated "Assise à Neolobites vibrayeanus" - is present in the whole basin. The upper part consists of two main facies: limestones with rudists in the south of the basin (from Leiria to Lisbon) and ammonite-bearing limestones in the north (from Leiria to Figueira da Foz and Coimbra). A third facies, marls with echinoids, is developed in the eastern part of the basin around Vila Nova de Ourem. The relationships between these facies are well known (Choffat 1900; Berthou 1973; Berthou \& Lauverjat 1976, 1979; Crosaz 1976; Crosaz-Galletti 1979; Moron 1981; Lauverjat 1982) (Fig. 1).

The lower part of the upper Cenomanian

The Cenomanian microfauna is well represented (Praealveolina simplex, $P$. cretacea Reichel, $P$. tenuis Reichel, Ovalveolina ovum, Cisalveolina fraasi (Gumbel), Pseudorhipidionina casertana (de Castro), Biconcava bentori) and distributed in four levels (Berthou 1973; Berthou et al. 1979). The ammonites are: Neolobites vibrayeanus (d'Orbigny) more or less frequent, Eucalycoceras pentagonum (Jukes-Browne), $\mathrm{Ca}$ lycoceras naviculare (Mantell), Thomelites ex gr. hancocki Kennedy \& Juignet, Calycoceras cf. robustum Thomel (all very rare), and there is one nautiloid: Angulithes mermeti (Coquand), more or less common.

Two types of subdivisions were established by Choffat. In the north of the basin (ammonite facies, northern part of rudist facies, and echinoid facies) the beds are designated by a letter and a name: C-beds with Neolobites vibrayeanus, D-beds with Anorthopygus michelini, and E-beds with Exogyra columba. In the south of the basin (entirely in rudist facies; area of Lisbon and Runa) the beds are numbered in each section. Choffat did not establish correlations between his mainly lithological subdivisions of the lower part of the upper Cenomanian.

I have mainly used the microfaunas to correl-

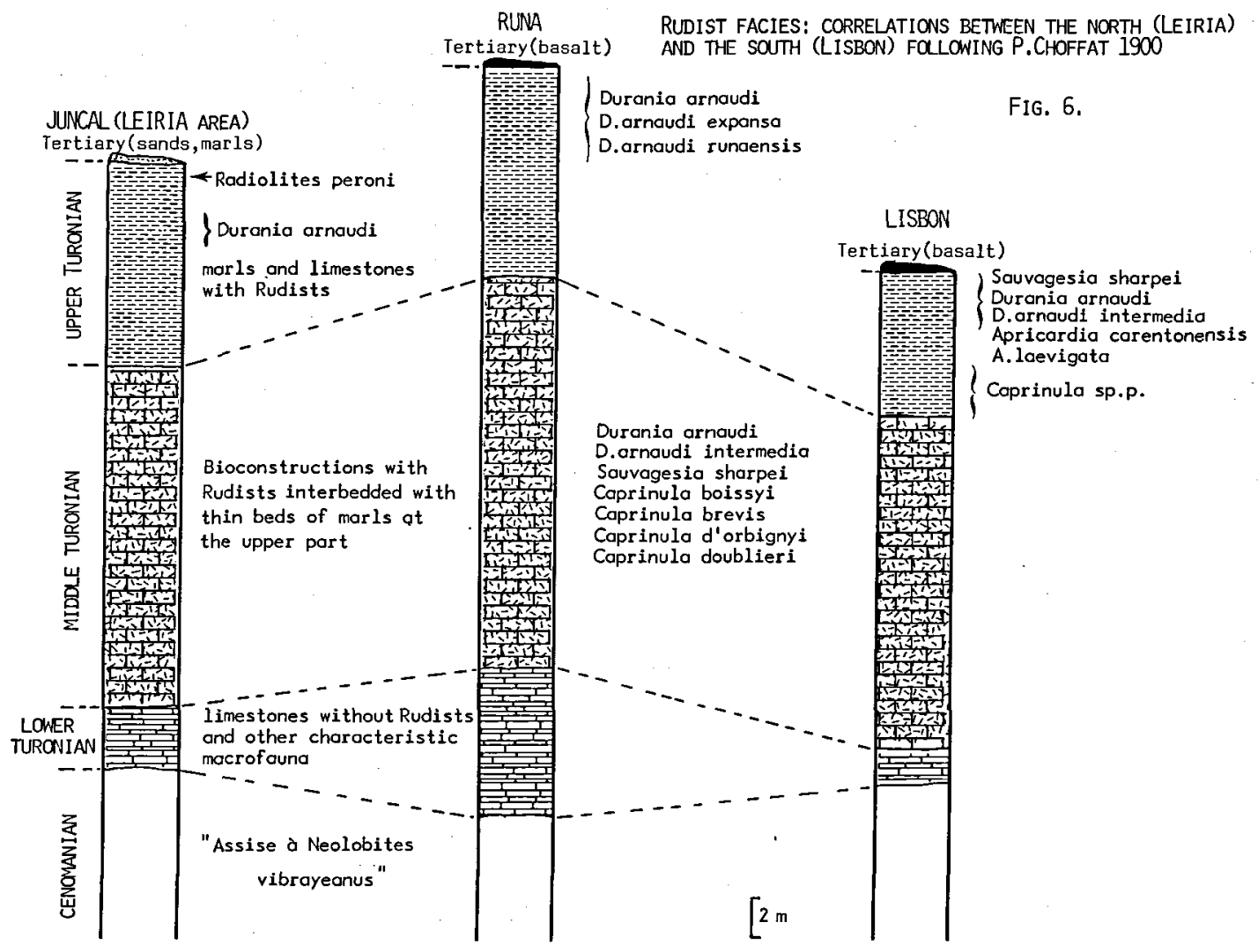


ate the sections. Indeed, almost all sections contain a bed with abundant Praealveolina tenuis (level 2), which allows correlation between the new sections and Choffat's sections, since Choffat consistently stated the position of this bed (Fig. 3). An interesting fact stands clear: level $D$ in the northern part of the basin (occasionally also level $\mathrm{E}$ ) is equivalent to the higher beds with Neolobites vibrayeanus, Calycoceras and Cisalveolina fraasi from the southern part. So, as can be seen below, the occurrence of Cenomanian ammonites and microfossils in level $E$ in the ammonite facies is normal.

The upper part of the upper Cenomanian, the Cenomanian-Turonian boundary and the lower Turonian

\section{Ammonite facies}

The ammonite facies is the stratigraphically most important of the three upper Cenomanian facies. The Cenomanian-Turonian transition and the lower Turonian - all well dated with ammonites are developed in this facies.
The subdivision of the sequence was made by Choffat (1900). Above the levels C, D and E there follow F, G, H, I, J, K, L, M, N, and O. These levels are characterized firstly on lithological grounds and, secondarily, on their fossil content. In some sections the sequence ends with fine-grained sandstones lacking ammonites or other significant macrofossils.

Choffat (1897a, 1897b, 1898, 1900) found two ammonite faunas in levels $\mathrm{E}$ to $\mathrm{O}$. One of the faunas was known previously and could therefore be used for dating the beds. viz. Fagesia superstes (Kossmat), F. thevestensis (Peron), Pseudaspidoceras cf. footeanum (Stoliczka), Pusozia cf. planulata (Sowerby), Pseudotissotia n.sp., Pachydiscus n.sp. and Neolobites sp. (Fig. 4).

The other fauna contains all the species of Vascoceras described by Choffat and "Acanthoceras(?)" pseudonodosoides. These forms were not placed in the stratigraphical framework by d'Orbigny in his definition of the Cenomanian and Turonian stages (d'Orbigny 1840-1842, 1850) and so were of little stratigraphical value for Choffat (Fig. 4).

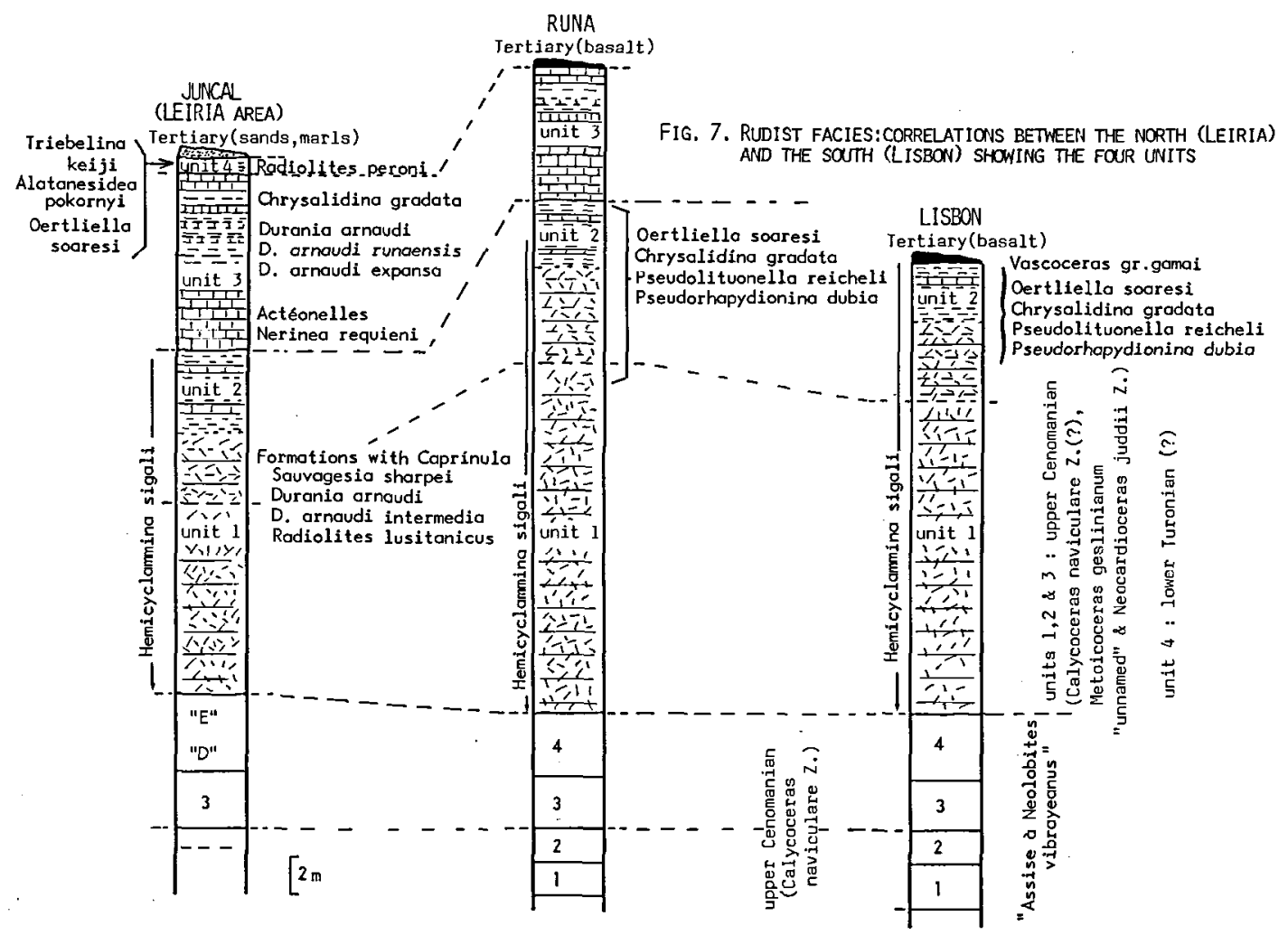


After much hesitation, Choffat (1900) published a stratigraphic scheme based mainly on lithology (Fig. 4):

Upper Turonian: levels $\mathrm{M}, \mathrm{N}, \mathrm{O}$ and micaceous, fine-grained sandstones; there is no palaeontological support for this assignment.

Middle Turonian: nodular limestones, ranging from level $\mathrm{F}$ to $\mathrm{L}$.

Lower Turonian: levels D and E.

Choffat specified that the Turonian age of levels $D, E$ and $F$ is doubtful. It is evident that his stratigraphical interpretation is incorrect as pointed out by Haug in 1911.

Based on new data in palynology, micropalaeontology and the ammonite occurrences, a revision has been made, which also takes into consideration the most recent concept of the Cenomanian (Hancock \& Kennedy 1980; Kennedy et al. 1980, 1982) (Fig. 5).

The micaceous, fine-grained sandstones above the ammonite-bearing limestones have been dated as early Turonian (Medus et al. 1980; Moron 1981). By comparison with other European lower Turonian sequences, it appears that the sandstones belong in the Mammites nodosoides Zone, although they do not reach the top of the zone (Medus et al. 1980).

This dating evidently implies that the carbonate sequence below cannot be younger than earliest Turonian.

Level D yields Praealveolina simplex and the Cenomanian echinoids Anorthopygus orbicularis (Grateloup) and A. michelini Cotteau.
In level $\mathrm{E}$, there is still a Cenomanian microfauna containing Praealveolina simplex, Thomasinella punica Schlumberger and Hemicyclammina sigali Maync and the echinoid Anorthopygus orbicularis. Neolobites sp. was noted by Choffat, and we have also recorded Euomphaloceras cf. cunningtoni tuberculata (Pervinquière) (Amedro et al. 1980). At this level in the Cenomanian the first Vascoceras ex gr. gamai Choffat and Vascoceras barcoicensis Choffat appear (Berthou et al. 1975).

Level F contains Thomasinella punica and $\mathrm{He}$ micyclammina sigali (which are restricted to the Cenomanian) as well as Pseudocalycoceras sp. and Calycoceras aff. bruni (Fabre) (Amedro et al. 1980). It is at this level that Vascoceras ex gr. gamai and $V$. barcoicensis are most abundant.

The Cenomanian age for the first appearance of Vascoceras in the type sections of the lower Mondego river is in agreement with the presence of Vascoceras in the stratotype of the Cenomanian (Kennedy \& Juignet 1977).

Levels $\mathrm{E}$ and $\mathrm{F}$ may be assigned to the Metoicoceras geslinianum Zone, following Kennedy \& Hancock (1977), although the base of level E may belong to the Calycoceras naviculare Zone.

Above level F, at levels G, H, I and J, I have not found any typically Cenomanian ammonites, nor any typical Cenomanian microfossils. At the top of $\mathrm{H}$ and at $\mathrm{I}$ and $\mathrm{J}$ there occur Pachyvascoceras douvillei (Choffat), Pseudaspidoceras footeanum, P. pseudonodosoides (Choffat) and Vascoceras subconciliatus Choffat. The latter species,

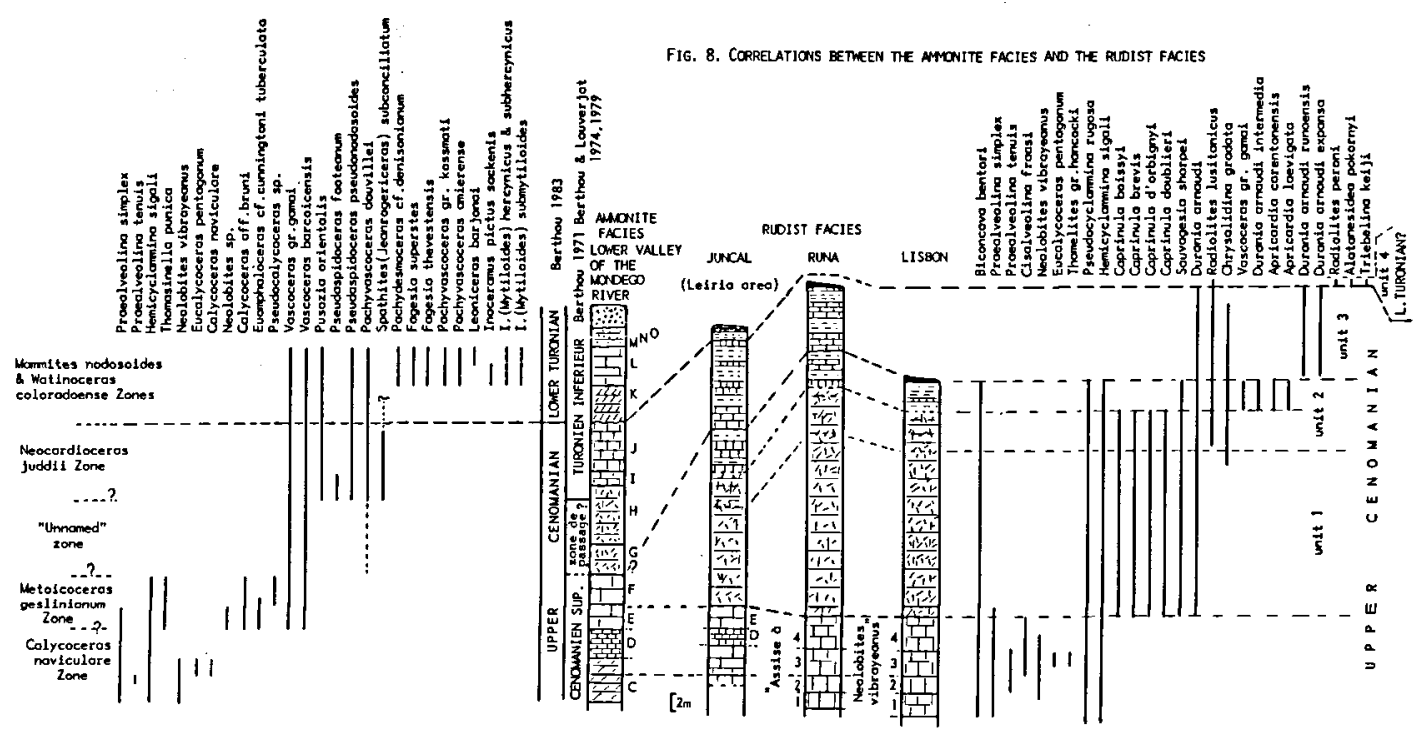

4 D.G.F. 33 
now regarded as belonging in the genus and subgenus Spathites (Jeanrogericeras) (Kennedy et al. 1980 ) is restricted to these levels.

Previously, level $\mathrm{G}$ and the lower part of $\mathbf{H}$ were regarded as boundary beds (Berthou \& Lauverjat 1975) or as doubtful Turonian (Berthou \& Lauverjat 1979). Recently, Spathites (J.) subconciliatus has been placed in the uppermost Cenomanian Neocardioceras juddii Zone (Hancock \& Kennedy 1980; Kennedy et al. 1982). In the sections of the lower Mondego river, there is a clear discontinuity at the top of $J$, the surface of which is locally karstified. Level $\mathrm{K}$ above this surface is dolomitic.

Following the recent developments, I propose to place the Cenomanian-Turonian boundary at the top of level $\mathrm{J}$. This new position is in harmony with the fossil content, because typically Turonian ammonites appear only at level $\mathrm{L}$.

The uppermost part of $\mathbf{H}$ and levels $\mathbf{I}$ and $\mathbf{J}$ may be regarded as equivalent of the Neocardioceras juddii Zone, and the subjacent levels $G$ and most of $\mathrm{H}$ as equivalent to the so-called "unnamed zone" of Kennedy et al. (1982). This "unnamed zone" yielded only very sparse, small and globose Vascoceras.

The dolomitic level $\mathrm{K}$ provides neither macrofossils nor microfossils. Level L yielded Turonian ammonites: Fagesia superstes (Kossmat), $F$. thevestensis (Peron), Leoniceras barjonai (Choffat), and Pachydesmoceras cf. denisonianum (Spath), Pachyvascoceras ex gr. kossmati (Choffat), $P$. amierense (Choffat). It should be noted that no Mammites nodosoides have been found. At level $\mathrm{L}$ there are also Inoceramus pictus sackenis Keller, I. (Mytiloides) hercynicus Petraschek, I. (Mytiloides) subhercynicus Seitz, and I. (Mytiloides) submytiloides Seitz (PI.1). Following the conclusions of the Colloquium on the Turonian (Paris 1982), this association is possible only in the lowermost Turonian. The last limestone levels $M, N$, and $O$, yielded no ammonites, and no significant macro- or microfauna. Detrital material (quartz and mica) appears at these levels.

Level $\mathrm{L}$ is probably equivalent to a part of the Watinocras coloradoense Zone, and to the basal and middle part of the Mammites nodosoides Zone.

The Mammites nodosoides Zone is also probably represented by the micaceous, fine-grained sandstones at the top of the sequence, according to the palynological data, as stated above.

\section{Rudist facies}

Choffat $(1897 b, 1900)$ established the "Turonian" age of the rudist limestones only through lithological correlation with the ammonite facies; this was in contradiction with available palaeontological data and also with his own previous interpretations! Indeed, in 1885 , on the basis of the palaeontological content, Choffat placed the rudist beds in the Cenomanian ("Carentonin" facies) and remarked that it would be a great error to assign these rudists (Sauvagesia sharpei, caprinulas, etc.) to the Turonian! He maintained this interpretation in 1886 and 1894 and never clearly deviated from it.

Choffat was right in correlating the first rudist beds with level $\mathrm{E}$ in the ammonite facies. However, his correlations between the northern and the southern parts of the rudist facies on one hand, and between the ammonite facies and rudist facies on the other hand, were erronous.

As for the ammonite facies, Choffat recognized three parts in the rudist facies based only on the lithology: at the base, hard limestones without rudists (lacking also Neolobites), then bioherms with rudists (mainly caprinulas), and at the top, marls with occasional limestone beds which locally contain rudists. He correlated the upper part with his "upper Turonian" of the ammonite facies! He placed the bioherms with caprinulas in the "middle Turonian" and the lower part in the "lower Turonian" (Fig. 6)!

This means that the marls with Radiolites peroni (Choffat), which constitute the uppermost level of the rudist beds, in the area of Leiria, and the marls with Sauvagesia sharpei (Bayle), Durania arnaudi intermedia (Choffat) and caprinulas ending the rudist beds in the Lisbon area would be upper Turonian. This is an error. In the same way Choffat attributed to the middle Turonian the typical Cenomanian caprinulas Caprinula brevis (Sharpe), C. dorbignyi (Sharpe), $C$. boissyi (d'Orbigny) and $C$. doublieri (d'Orbigny).

The limestones below the first appearance of rudists belong to the top (the fourth part) of the beds with Neolobites vibrayeanus s.l., containing rare Praealveolina simplex and Cisalveolina fraasi (Fig. 7). The rudist beds above are divisible into four units. 
Unit 1 belongs to the bioherms with the Cenomanian caprinula assemblage of Sauvagesia sharpei (Bayle), Durania arnaudi (Choffat) (doubtful at the base); very rare Praealveolina simplex sometimes occur at the base. Unit 2 consists of beds with the same rudists but no bioherms with caprinulas. The caprinulas disappear in the lower part. Radiolites lusitanicus (Bayle) and Durania arnaudi intermedia (Choffat) appear in the upper part of unit 2. It yields a Cenomanian microfauna with Chrysalidina gradata (d'Orbigny) and Hemicyclammina sigali Maync. A single Vascoceras ex gr. gamai was found by Choffat at the top.

In the Lisbon area, Palaeogene basalts overly unit 2.

In the Runa basin, $50 \mathrm{~km}$ north of Lisbon, the sequences are better preserved, and one can recognize unit 2 with the same microfauna as in the Lisbon area. Above, unit 3 begins with limestones containing Nerinea (e.g. Nerinea requieni d'Orbigny) and acteonellid gastropods, followed by one or two thin beds with Durania arnaudi, $D$. arnaudi expansa (Choffat) and $D$. arnaudi runaensis (Choffat). Unit 3 is overlain by the Palaeogene basalts.
In the northern part of the area of rudist facies, around Leiria, unit 1 is thinner, unit 2 yields only Hemicyclammina sigali, and unit 3 contains very scarce Chrysalidina gradata; all data point to a Cenomanian age for unit 3.

Unit 4 , which occurs only in the northern part of the area of rudist facies, consists of marls with very abundant Radiolites peroni (Choffat) and some $R$. lusitanicus (Bayle). There are no $\mathrm{Du}$ rania and no diagnostic microfossils, but ostracodes known from close to the CenomanianTuronian boundary in the Mediterranean realm (Babinot 1980) appear: Alatanesidea pokornyi Colin \& Lauverjat and Triebelina keiji Colin \& Lauverjat (Figs 7-8). A discontinuity surface divides units 3 and 4 of the rudist beds; the top of unit 3 is marked by detrital quartz. The discontinuity surface is hardened, ferruginous and irregular.

The stratigraphy of the rudist beds in Portugal is similar to equivalent Cenomanian and Cenomanian-Turonian beds in Provence (France) (Berthou \& Philip 1972, Philip 1978).

Figure 8 shows the clear correlation between the ammonite and rudist facies.

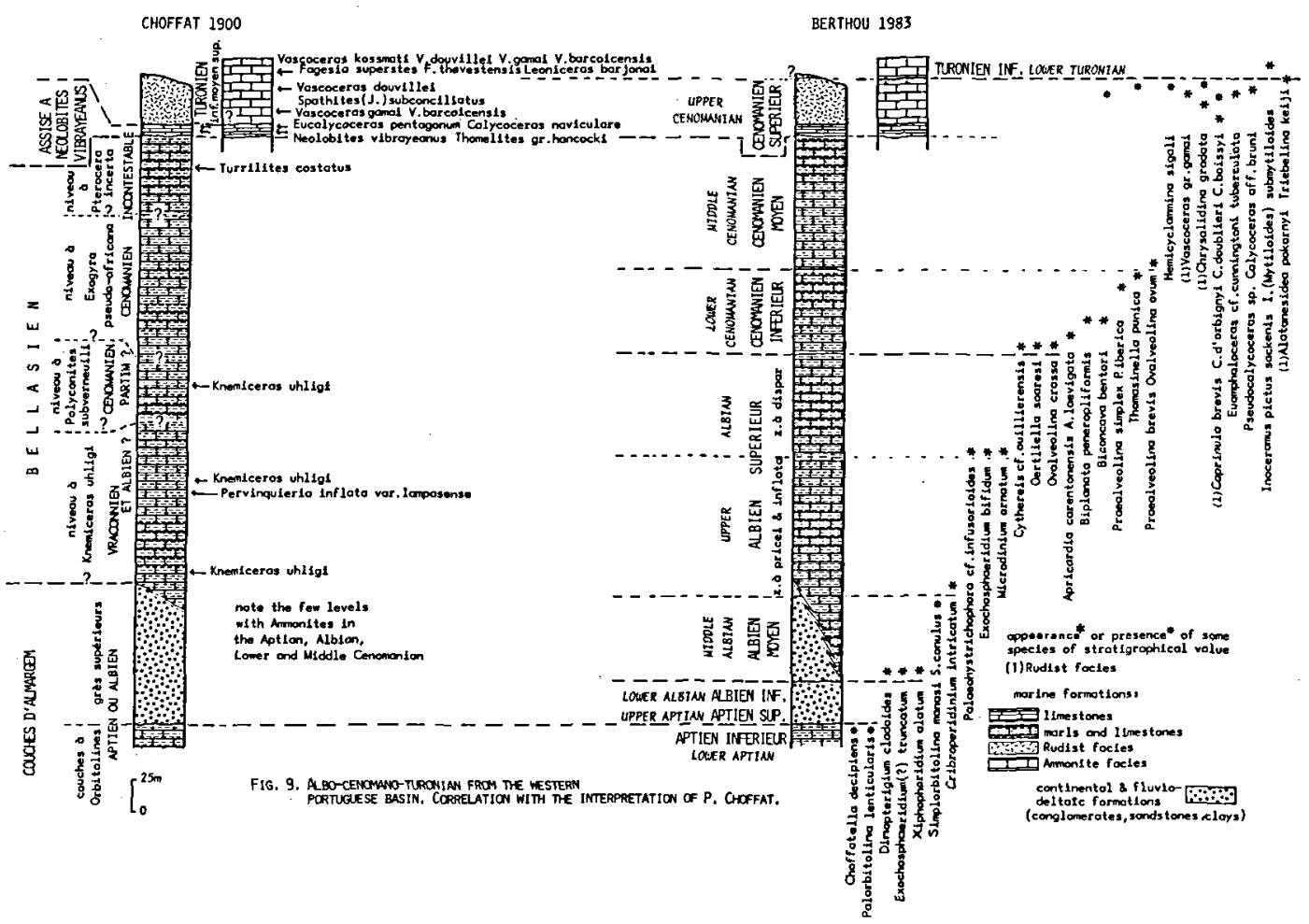


The rudists appear in the upper part of level E.

Unit 1 (bioherms with caprinulas and Sauvagesiinae) and unit 2 (limestones and marls with chiefly Durania arnaudi intermedia) correspond to level F, judging by the presence of Vascoceras ex gr. gamai and Hemicyclammina sigali. The top of unit 2, where $H$. sigali disappears, may possibly be correlated with level $G$.

Unit 3 is equivalent to levels $\mathrm{G}(?), \mathrm{H}$, I and $\mathrm{J}$. The introduction of detrital quartz at the top of unit 3 of the rudist beds is an important feature, as is the discontinuity surface at the top of level J. These are perhaps caused by the same geodynamic event at the Cenomanian-Turonian boundary. Using these hypothesis, unit 4 of the rudist beds will be equivalent to level $\mathrm{K}$, or perhaps $K$ and $L$ and also the top of $J$. Under all circumstances, it belongs to the CenomanianTuronian boundary or to a level slightly above the boundary.

As a result of these correlations, it appears that Sauvagesia sharpei and Durania arnaudi intermedia do not survive the Cenomanian in Portugal (Metoicoceras geslinianum Zone). Durania arnaudi, $D$. arnaudi expansa and $D$. arnaudi runaensis reach the Neocardioceras juddii Zone, i.e. uppermost Cenomanian or lowermost Turonian, depending on the definition used. Radiolites lusitanicus appears in the upper Cenomanian and reaches into the lower Turonian. Radiolites peroni appears at the Cenomanian-Turonian boundary and extends through the lower Turonian.

\section{Echinoid facies}

The upper Cenomanian echinoid marls in the eastern part of the basin, around Vila Nova de Ourem, yields an echinoid fauna consisting of Diplopodia deshayesii Cotteau, D. variolaris (Brongniart), D. cf. depauperata de Loriol and the foraminifer Hemicyclammina sigali. They are a lateral equivalent of units 1 and 2 of the rudist beds, the intertonguing of these two facies being visible in outcrop. They are also equivalent to levels $\mathrm{E}$ and $\mathrm{F}$ of the ammonite facies (CrosazGaletti 1979), which was further supported by palynological data (Moron 1981).

\section{Conclusions}

Comparison between stage and substage boundaries now in use from the Aptian to the Turonian with those established by Choffat (1885-1900) shows only one common point: The boundary between the middle and upper Cenomanian (Fig. 9).

From the Aptian to the upper Cenomanian the scarcity of ammonite-bearing levels and the lack of planktonic Foraminifera have called for the use of various fossil groups in the stratigraphical work, in particular dinocysts and large benthic Foraminifera. The stratigraphic ranges of these auxiliary fossils are well defined, particularly in the Tethyan Realm.

The stratigraphic revision of the three upper Cenomanian facies has clearly pointed out the errors of Choffat in his correlations between the different sections in one facies (e.g., rudist facies), or between the facies, and in his datings which rarely take into account the fossils contained in the sequence.

The most frequent species of the Calycoceras naviculare Zone is Neolobites vibrayeanus, which is restricted to the zone.

Higher up in the sequence, the interval-zone with Vascoceras ex. gr. gamai and $V$. barcoicensis is in the position of the Metoicoceras geslinianum Zone; it belongs to the Cenomanian, as proven by the occurrence of Calycoceras, Pseudocalycoceras and Euomphaloceras. The acme of the Vascoceras gamai group is in the Metoicoceras geslinianum Zone but, these forms transgress the Cenomanian-Turonian boundary.

Above, there are limestone beds which correspond to the "unnamed zone" and to the Neocardioceras juddii Zone; the latter is marked in Portugal by Spathites (J.) subconciliatus. These beds represent the interval-zone with Pachyvascoceras douvillei-durandi, which was proposed as the lowest zone of the Turonian by Collignon (1971).

The Pachyvascoceras douvillei-durandi group appears perhaps in the higher part of the Metoicoceras geslinianum Zone and the acme is in the Neocardioceras juddii Zone. This group transgresses the Cenomanian-Turonian boundary.

I have not yet taken a definite standpoint, but it is clear that the Cenomanian-Turonian boundary in Portugal will be better defined if we regard the Neocardioceras juddii Zone as uppermost 

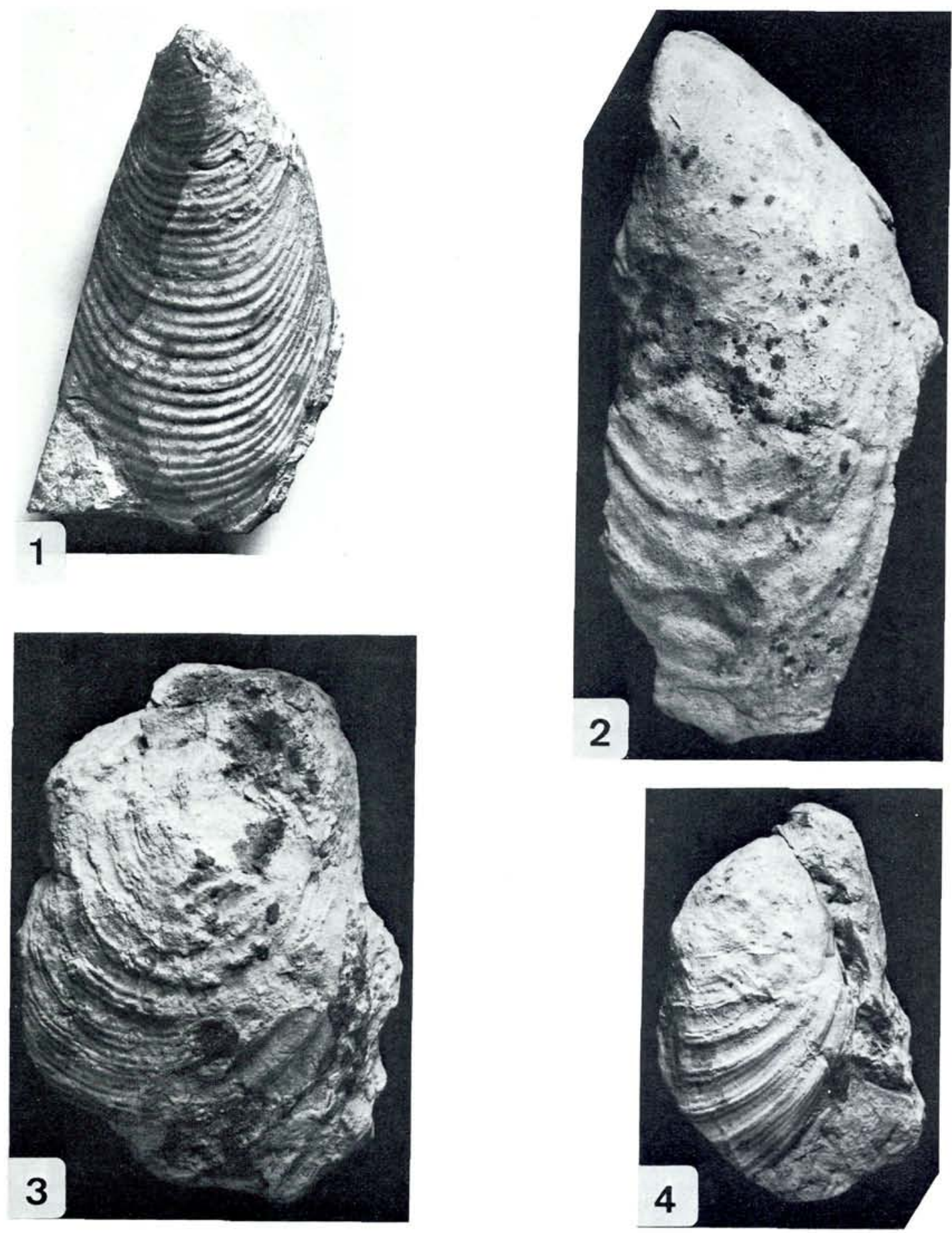

Plate 1. Inoceramids from the lower Turonian (lower valley of the Mondego river) 1 - Inoceramus pictus sackenis Keller (lower part of the level " $L$ ") $\times 1$

2 - Inoceramus (Mytiloides) submytiloides Seitz (level "L") $\times 1$

3 - Inoceramus (Mytiloides) hercynicus Petraschek_(level "L") $\times 1$

4 - Inoceramus (Mytiloides) subhercynicus Seitz (level "L") $\times 1$ 
Cenomanian, following the suggestion of Kennedy et al. (1982). The position of the Cenomanian-Turonian boundary at the top of the Neocardioceras juddii Zone provides better and easier correlations between the Boreal and the Tethyan realms.

The Turonian will then begin with the Fagesia superstes intervalzone $(=$ ? Watinoceras coloradoense Zone). The Pachyvascoceras kossmati group occurs only in the lowermost Turonian (Watinoceras coloradoense Zone and lower part of the Mammites nodosoides Zone).

This position of the Cenomanian-Turonian boundary will place part of the vascoceratids in the Cenomanian. The presence of Vascoceras in the Cenomanian is now recognized in the Sahara by Amard \& al. $(1977,1981)$.

The western Portuguese Basin is a good area to correlate ammonite facies and rudist facies at the Cenomanian-Turonian boundary. With the Neocardioceras juddii Zone as uppermost Cenomanian, Durania arnaudi will be restricted to the Cenomanian in Portugal. Only Radiolites peroni begins at the Cenomanian-Turonian boundary and occurs in the lower Turonian. Radiolites lusitanicus appears in the Cenomanian and transgresses the Cenomanian-Turonian boundary. Sauvagesia sharpei and Durania arnaudi intermedia are restricted to the Calycoceras naviculare and Metoicoceras geslinianum Zones.

Regarding the stratigraphic ranges of the large benthic Foraminifera, it appears that, except for Chrysalidina gradata, the typical Cenomanian forms, e.g. Praealveolina simplex, Cisalveolina fraasi, Thomasinella punica, and Hemicyclammina sigali, do not extend above the Metoicoceras geslinianum Zone. The "unnamed zone" and the Neocardioceras juddii Zone seem fairly poor in benthic Foraminifera. Chrysalidina gradata reaches the Neocardioceras juddii Zone, and Trochospira avnimelechi also ends at that level in Portugal (Berthou 1983). The lower Turonian is poor in benthic Foraminifera and lacks characteristic species.

Acknowledgments. I am indebted to Dr. Sornay (National Museum of Natural History, Paris) for the determinations of inoceramids and to the late General Collignon for the revision of some ammonites from the Choffat's collection. I also thank J. Kennedy (Oxford University), J. Hancock (King's College, London), F. Amedro (Calais), J. Philip (University of Pro- vence), A. Bidar (Museum of Natural History, Nice) and E. Seibertz (Linares, Mexico) for their help in the study of Ammonites, Rudists, Echinoids and Inoceramids. Many thanks also to Dr. Peter Bengtson (Uppsala) who has had the task of correcting my English.

Contribution to the IGCP Project $\mathrm{n}^{0} 58$ :

"MID CRETACEOUS EVENTS".

\section{Dansk Sammendrag}

Etagegrænser fra aptien-albien til cenomanien-turonien er fastlagt $\mathbf{i}$ det vestportugisiske bassin. Cenomanien-turonien grænsen er sarlig grundigt behandlet; ammonitfacies og rudistfacies omkring denne granse er korreleret.

\section{References}

Amard, B., Berthou, P. Y. and Collignon, M. 1977: Le Cénomanien supérieur et le Turonien inférieur du Tademaït-E et du Tinrhert-W (Sahara algérien): relations stratigraphiques et paléontologiques; comparaisons avec les régions voisines et le Portugal. C.R.Ac.Sc. Paris 284, 9-11.

Amard, B., Collignon, M. and Roman, J. 1981: Etude stratigraphique et paléontologique du Crétacé supéricur et $\mathrm{Pal}-$ éocène du Tinrhert-W et Tademaït-E (Sahara algérien). Doc. Lab. Geol. Lyon H.S. 6, 15-173.

Amedro, F. 1981: Actualisation des Zonations d'Ammonites dans le Crétacé moyen du Bassin Anglo-parisien. Essaj d'une Zonation Phylétique de l'Albien au Turonien. Cret. Res. 2(3/4) 261-269.

Amedro, F., Berthou, P. Y. and Lauverjat, J. 1980: Nouvelles preuves de l'apparition au Cénomanien supérieur des premiers Vascoceras dans la série type de la basse vallée du rio Mondego (Beira litoral, Portugal), Bol. Soc. Geol. Portugal XXII, 153-161.

Babinot, J. F. 1980: Les Ostracodes du Crétacé supérieur de Provence. Thèse ès-Sciences, Université de Provence, $2 t$. ronéotés, $634 \mathrm{pp}$.

Berthou, P. Y. 1973: Le Cénomanien de l'Estrémadure portugaise. Mem. Serv. Geol. Portugal n.s. 23, 168 pp.

Berthou, P. Y. (in press): Répartition stratigraphique actualisée des principaux Foraminifères benthiques du Crétacé moyen et supérieur du Bassin occidental portugais. Bull. Cent. Rech. Explor.-Prod. Elf-Aquitaine Mem.

Berthou, P. Y., Brower, J. C. and Reyment, R. A. 1975: Morphometrical study of Choffat's Vascoceratids from Portugal. Bul. Geol. Inst. Univ. Uppsala N.S. 6, 73-83.

Berthou, P. Y., Ferreira Soares, A. and Lauverjat, J. 1979: Mid Cretaceous Events. Iberian Field Conference 1977. Guide lère partie: Portugal. Cua. Geol. Ibe. Madrid 5, 31-124.

Berthou, P. Y., Hasenboehler, B. \& Moron, J. M. 1981: Apports de la Palynologie à la stratigraphie du Crétacé moyen et supérieur du Bassin occidental portugais. Mem. Not. Coimbra 91-92, 183-221.

Berthou, P. Y. and Hasenboehler, B. (in press): Les kystes de Dinoflagellés de l'Albien et du Cénomanien de la région de Lisbonne (Portugal). Répartition et intérêt stratigraphique. Cua. Geol. Ibe. Madrid.

Berthou, P. Y. and Lauverjat, J. 1975: Le Cénomano-Turonien à Vascocératidés dans sa région type (embouchure du rio Mondego, Beira liftorale, Portugal). Corrélations avec le stratotype du Mans et d'autres séries téthysiennes. Newsl. Strat. 4(2) 96-118. 
Berthou, P. Y. and Lauverjat, J. 1976: La limite CénomanienTuronien dans les principaux faciès du Bassin occidental portugais. C.R.Ac. Sc. Paris 282, 2143-2146.

Berthou, P. Y. and Lauverjat, J. 1979: Essai de Synthèse paléogéographique et paléobiostratigraphique du Bassin occidental portugais au cours du Crétacé supérieur. Ciencias Terra Lisboa 5, 121-144.

Berthou, P. Y. and Philip, J. 1972: La limite CénomanienTuronien dans les formations récifales du domaine mésogéen. C. R. Som. Soc. Géol. France 6, 238-239.

Berthou, P. Y. and Schroeder, R. 1978: Les Orbitolinidae et Alveolinidae de l'Albien supérieur-Cénomanien inférieur dans le Sud-Ouest de la région de Lisbonne (Portugal). Cah. Micropal. Paris 3, 51-103.

Berthou, P. Y. and Schroeder, R. 1979: Découverte d'un niveau à Simplorbitolina CIRY RAT dans l'Albien de Guincho (région de Lisbonne, Portugal). C. R. Ac. Sc. Paris 288, 591-594.

Choffat, P. 1885: Recueil de monographies stratigraphiques sur le système crétacique du Portugal. Première étude: contrées de Cintra, Bellas et Lisbonne. Mem. Sec. Trab. Geol. Portugal, 76 pp.

Choffat, P. 1886: Recueil d'études paléontologiques sur la faune crétacique du Portugal. Vol. 1: Espèces nouvelles ou peu connues. 1ère série. Mem. Sec. Trab. Portugal, 40 pp.

Choffat, P. 1894: Notice stratigraphique sur les gisements de végétaux fossiles dans le Mésozoïque du Portugal. In SAPORTA M. de,- Flore fossile du Portugal. Nouvelles contributions à la flore mésozoïque. Mem. Dir. Trab. Geol. Portugal, 229-282.

Choffat, P. 1897a: Sur le Crétacique de la région du Mondego. C. R. Ac. Sc. Paris 124, 422-424.

Choffat, P. 1897b: Parallélisme entre le Crétacique du Mondego et celui de Lisbonne. Le Garumnien en Portugal. C. R. Ac. Sc. Paris 124, 519-521.

Choffat, P. 1898: Recueil d'études paléontologiques sur la faune crétacique du Portugal. Espèces nouvelles ou peu connues. 2ème série: Les Ammonées du Bellasien, des couches à Neolobites vibrayeanus, du Turonien et du Sénonien. Mem. Dir. Trab. Geol. Portugal, 46 pp.

Choffat, P. 1900: Recueil de monographies stratigraphiques sur le systéme crétacique du Portugal. 2è étude. Le Crétacique au Nord du Tage. Mem. Dir. Serv. Geol. Portugal, 287 pp.

Collignon, M. 1971: Zones d'Ammonites du Turonien au Maestrichtien (essai provisoire, nov. 1971). In: Biostratigraphie du Crétacé supérieur, Groupe Français du Crétacé Ronéoté inédit, 3-8.

Crosaz-Galetti, R. 1979: Etude stratigraphique et micropaléontologique du Cénomanien calcaire de la région de Vila Nova de Ourem (Portugal). Com. Serv. Geol. Portugal 65, 47-104.

Damotte, R., Babinot, J. F. and Colin, J. P. 1981: Les Ostracodes du Crétacé moyen Européen. Cret. Res. 2(3/4) 287306.

Davey, R. J. 1979: Marine Apto-Albian palynomorphs from Holes 400A and 402A, IPOD, Leg 48, Northern Bay of Biscay. Init. Rep. Deep Sea Dril. Proj. 48, 547-577.

Fauconnier, D. 1977: Les Dinoflagellés de l'Albien et du Cénomanien inférieur du bassin de Paris. Répartition stratigraphique et relation avec la nature du dépôt. Doc. Bur. Rech. Geol. Min. 5, 186 pp.

Foucher, J. C. 1981: Kystes de Dinoflagellés du Crétacé moyen Européen: proposition d'une échelle biostratigraphique pour le domaine nord-occidental. Cret. Res. 2(3/4), 331338.

Graciansky, P. C. de, Brosse, E., Deroo, G., Herbin, J.-P., Montadert, L., Müller, C., Sigal, J. and Schaaf, A. 1982: Les formations d'âge crétacé de l'Atlantique Nord et leur matière organique: paléogéographie et milieux de dépôt. Rev. Inst. Fr. Pétr. 37(3), 275-336.
Hancock, J. M. \& Kennedy, W. J. 1980: Upper Cretaceous ammonite stratigraphy: some current problems. In House, M. R. \& Senior, J. R.: The Ammonoidea. Syst. Ass. Sp. Vol. 18, 531-553.

Hasenboehler, B. 1981: Etude Paléobotanique et Palynologique de l'Albien et du Cénomanien du Bassin Occidenta Portugais au sud de l'accident de Nazaré (Province d'Estrémadure, Portugal). Mem. Sc. Terre Paris 18-29, 317 pp.

Haug, E. 1911: Traité de Géologie. Armand Colin Ed. Paris, $2020 \mathrm{pp}$.

Kennedy, W. J. and Hancock, J. M. 1977: Towards a correlation of the Cenomanian sequences of Japan with those of north-west Europe. Pal. Soc. Japan sp. pap. 21, 127-141.

Kennedy, W. J. and Juignet, P. 1977: Ammonites diartianus D'Orbigny, 1850, Vascoceratidae du Cénomanien supérieur de Saint-Calais (Sarthe). Geobios 10 (4), 583-595.

Kennedy, W. J., Wright, C. W. and Hancock, J. M. 1980: Origin, evolution and systematics of the Cretaceous ammonite Spathites. Palaeont. 23 (4), 821-837.

Kennedy, W. J., Wright, C. W. and Hancock, J. M. 1982: Ammonite zonation and correlation of the uppermost $\mathrm{Ce}$ nomanian and Turonian of southern England and the type areas of Sarthe and Touraine in France. Mem. Mus. Nat. Hist. Nat. n. s. C. $49,175-181$

Lauverjat, J. 1982: Le Crétacé supérieur dans le nord du Bassin Occidental Portugais. Mem. Sc. Terre Paris 82-16, 717 pp.

Martins Carvalho, J., Lopo Mendonca, J. J., Berthou, P. Y. and Blanc, Ph. 1982: Etude géologique et hydrogéologique des forages d'Estoril. III Semana Hidrogeol. Pub. Centro Geol. Lisboa, 379-437.

Masure, E. and Hasenboehler, B. 1981: Répartition des Dinokystes Apto-albiens de la marge portugaise. Poster " $\mathrm{Hex}$ rose" Conf. Mod. Fos. Dino. Tübingen.

Masure, E. and Hasenboehler, B. (in press): The Aptian and Albian dinocysts "communities' from the portuguese margin (Drill Site 398 D. Leg 47 B) and the Portuguese occidental basin and their use in palaeogeography. Palynology

Medus, J., Boch, A., Parron, C., Lauverjat, J. \& Triat, J. M. 1980: Turonian normapolles from Portugal and Southern France, correlations. Rev. Paleobot. Palyno. 31, 105-153.

Moron, J. M. 1981: Etude Paléobotanique et Palynologique du Crétacé supérieur du Bassin occidental portugais au nord de l'accident de Nazaré (Portugal). Thèsé 3è cycle Paris 1 vol. ronéoté inédit, $287 \mathrm{pp}$.

Neumann, M., Schroeder, R., and Groupe Européen des Grands Foraminifères Benthiques, 1981: Tableau de Répartition stratigraphique des Grands Foraminifères caractéristiques du Crétacé moyen de la région méditerranéenne. Cret. Res. 2(3/4), 383-393.

Orbigny, A. d. 1840-1842: Paléontologie française. Terrains Crétacés. I. Céphalopodes. Masson Ed. Paris, 662 pp.

Orbigny, A. d'. 1850: Prodrome de Paleontologie stratigraphique universelle des animaux mollusques et rayonnés. II. Masson Ed. Paris, 427 pp.

Philip, J. 1978: Stratigraphie et paléoécologie des formations à Rudistes du Cénomanien l'exemple de la Provence. Géol. Médit. 5(1), 155-168.

Rey, J. 1972: Recherches géologiques sur le Crétacé inférieur de l'Estramadura, Portugal Thèse Dr. ès-Sc. Toulouse J. F. Impr. Ed., 529 pp.

Rey, J. 1979: Le Crétacé inférieur de la marge atlantique portugaise: biostratigraphie, organisation séquentielle, évolution paléogéographique. Ciencias Terra 5, 97-120.

Verdier, J. P. 1975: Les Kystes de Dinoflagellés de la section de Wissant et leur distribution stratigraphique au Crétacé moyen. Rev. Micropal. 17(4), 191-197. 